\title{
PENERAPAN MODEL PROBLEM BASED LEARNING (PBL) DENGAN MEDIA KARTU DOMINO DALAM PENINGKATAN PEMBELAJARAN MATEMATIKA TENTANG PECAHAN PADA SISWA KELAS V SDN 2 KLAPASAWIT TAHUN AJARAN 2017/2018
}

\author{
Mega Puspitasari ${ }^{1}$, Joharman $^{2}$, Wahyudi $^{3}$ \\ 1, 2, 3 Universitas Sebelas Maret \\ megapuspita16@gmail.com
}

\section{Article History}

accepted 01/06/2019

\begin{abstract}
The objectives of this research are to improve the learning of mathematics about fraction on the fourth grade student. The subjects were fourth grade students of SDN 2 Klapasawit, amounting to 20 students. This research was conducted in three cycles. Each cycle consisting of planning, action, observation, and reflection. The sources of data were from students, teachers, and document. The techniques of data collection were observation, interview, and test. The validity of the data used the triangulation of sources and technique. The analysis of data consisting of data reduction, data description, and conclusion. The results of the research indicate that the use of PBL models with domino card media can improve the learning of mathematics.
\end{abstract}

Keywords: PBL, Domino Card, Fraction

\begin{abstract}
Abstrak
Tujuan penelitian ini untuk meningkatkan pembelajaran matematika tentang pecahan pada siswa kelas V. Subjek penelitian adalah siswa kelas V SDN 2 Klapasawit yang berjumlah 20 siswa. Penelitian ini dilaksanakan dalam tiga siklus. Sumber data penelitian adalah siswa, guru, dan dokumen. Teknik pengumpulan data dengan observasi, wawancara, dan tes. Validitas data menggunakan triangulasi sumber dan teknik. Analisis data meliputi reduksi data, penyajian data, dan penarikan kesimpulan. Hasil penelitian menunjukkan penggunaan model $P B L$ dengan media kartu domino dapat meningkatkan pembelajaran matematika.
\end{abstract}

Kata kunci: Problem Based Learning, Kartu Domino, Pecahan 


\section{PENDAHULUAN \\ PENDAHULUAN}

Pendidikan adalah salah satu kunci dalam meningkatkan mutu sumber daya manusia, sebab dengan pendidikan dapat menambah pengetahuan, meningkatkan ketrampilan, dan dapat menanamkan nilai-nilai karakter bangsa dengan baik. Pembentukan karakter bangsa yang baik diwujudkan dengan proses pembelajaran yang berdasarkan pada tujuan pendidikan nasional.

Berdasarkan hasil observasi di SD Negeri 2 Klapasawit, proses pembelajaran Matematika masih jauh dari yang diharapan. Pertama, siswa hanya mendengarkan penjelasan guru, kemudian mencatat materi, dan mengerjakan soal-soal latihan. Kedua, siswa kesulitan ketika diminta mengerjakan soal dari pengembangan materi. Seperti pada materi pecahan, siswa tidak mampu menjelaskan pengertian pecahan serta masih kesulitan dalam mengerjakan soal yang berkaitan dengan pemecahan masalah bilangan pecahan. Kesulitan tersebut menunjukkan bahwa pemahaman konsep pecahan, pengerjaan operasi hitung pecahan, serta pemecahan masalah yang berkaitan dengan pecahan masih kurang. Ketiga, guru masih mendidik dengan metode teacher centered tanpa menggunakan media secara optimal dalam proses pembelajarannya. Guru hanya menggunakan papan tulis dan buku sebagai media pembelajaran, sehingga pemahaman konsep tentang pecahan serta pengembangan materi yang berkaitan dengan pecahan kurang tertanam secara maksimal. Hal tersebut menunjukkan bahwa model pembelajaran yang digunakan kurang inovatif serta kurangnya pemanfaatan media dalam proses pembelajaran di SD Negeri 2 Klapasawit.

Berdasarkan fakta-fakta yang telah di amati di lapangan, didapatkan bahwa pembelajaran yang dilaksanakan di SD Negeri 2 Klapasawit belum menggunakan model pembelajaran yang inovatif dan belum memanfaatkan media secara optimal untuk menunjang proses pembelajaran. Hal tersebut mengakibatkan rendahnya hasil belajar siswa pada mata pelajaran Matematika. Dari data yang diperoleh oleh peneliti, didapatkan hasil nilai ulangan tengah semester siswa yang masih rendah. Belum banyak siswa yang memenuhi Krtiteria Ketuntasan Mininal (KKM) yang telah ditetapkan oleh sekolah. KKM yang ditentukan oleh sekolah adalah 68. Dari 20 siswa, hanya ada 7 siswa yang memenuhi batas tuntas. Jika dibuat presentase, siswa yang sudah memenuhi batas ketuntasan atau KKM hanya 35\%, sedangkan 65\% siswa lainnya belum memenuhi batas tuntas yang ada. Selain itu, rata-rata nilai ulangan tengah semester siswa baru mencapai 59,6 sedangkan KKM yang dibuat oleh sekolah adalah 68. Dibandingkan nilai ulangan tengah semester yang lain, nilai rata-rata Matematika termasuk ketegori paling rendah. Nilai rata-rata IPA $=59,75$, nilai rata-rata Bahasa Indonesia $=70,1$, nilai rata-rata $P K n=60,45$, nilai rata-rata $I P S=59,8$, nilai ratarata Bahasa Jawa $=59,6$, nilai rata-rata Bahasa Inggris $=70$. Oleh karena itu, perlu adanya perbaikan dalam proses pembelajaran untuk meningkatkan kemampuan Matematika siswa, serta diperlukan media yang menarik yang dapat menunjang proses pembelajaran sehingga materi yang disampaikan dapat diterima dengan baik oleh siswa, sehingga hasil belajar siswa dapat meningkat dan target sekolah dapat tercapai.

Huda (2014: 6) mengemukakan bahwa pembelajaran merupakan suatu fenomena yang kompleks yang dipengaruhi oleh banyak faktor. Pembelajaran juga merupakan rekonstruksi dari pengalaman masa lalu yang berpengaruh terhadap tingkah laku dan kapasitas seseorang. Matematika merupakan bahan kajian yang memiliki objek abstrak serta dibangun melalui proses penalaran deduktif, yaitu kebenaran suatu konsep diperoleh sebagai akibat logis dari kebenaran yang telah ada sebelumnya dan diterima, sehingga kebenaran antar konsep dalam Matematika bersifat sangat kuat dan jelas (Wahyudi, 2015: 68). 
Peningkatan pembelajaran Matematika tentang pecahan pada siswa kelas V SD adalah proses penyampaian ilmu Matematika tentang pecahan yang meliputi mengubah bentuk pecahan biasa menjadi bentuk persen dan sebaliknya, mengubah bentuk pecahan biasa menjadi bentuk desimal dan sebaliknya, mengubah pecahan campuran menjadi pecahan biasa, mengubah pecahan campuran menjadi bentuk desimal, mengubah pecahan campuran menjadi bentuk persen, menentukan hasil penjumlahan pecahan biasa dengan penyebut sama, menentukan hasil penjumlahan pecahan biasa dengan penyebut berbeda, menentukan hasil pengurangan pecahan biasa dengan penyebut sama, dan menentukan hasil pengurangan pecahan biasa dengan penyebut berbeda pada siswa kelas V SD yang berada pada tahap operasional konkret dengan model dan media yang dapat menunjang proses pembelajaran, sehingga proses dan hasil belajar siswa menjadi lebih maksimal.

Menurut Dutch (dalam Amir, 2009: 21) Problem Based Learning (PBL) merupakan metode instruksional yang menantang siswa agar "belajar untuk belajar" bekerja sama dalam ke-lompok untuk mencari solusi bagi ma-salah yang nyata. Kartu domino merupakan kartu yang terbuat dari kertas tebal, memiliki ukuran yang kecil, berbentuk persegi panjang, terbagi menjadi dua bidang, dan pada setiap bidang memiliki nilai dalam bentuk bulatan (Nugraha, 2016: 32).

Model model Problem Based Learning (PBL) dengan media kartu domino merupakan suatu model pembelajaran berdasarkan masalah yang disajikan secara sistematis yang berkaitan dengan kehidupan nyata, kemudian siswa diarahkan untuk menyelesaikan masalah tersebut dari berbagai perspektif, sehingga siswa dapat menyusun pengetahuan mereka sendiri, mengembangkan inkuiri dan ketrampilan berpikir tingkat lebih tinggi, mengembangkan kemandirian dan percaya diri yang dikombinasikan dengan media kartu domino, sehingga siswa sungguh-sungguh mendapatkan pemahaman mengenai apa yang sudah dipelajari.

Rumusan masalah dari penelitian tindakan kelas secara kolaboratif ini yaitu: Apakah penggunaan model Problem Based Learning dengan media kartu domino dapat meningkatkan pembelajaran matematika tentang pecahan pada siswa kelas $\mathrm{V}$ SDN 2 Klapasawit Tahun Ajaran 2017/2018?

Berdasarkan rumusan masalah, maka tujuan penelitian ini yaitu: Untuk meningkatkan pembelajaran matematika tentang pecahan dengan menggunakan model Problem Based Learning dengan media kartu domino pada siswa kelas V SDN 2 Klapasawit Tahun Ajaran 2017/2018.

\section{METODE}

Penelitian ini merupakan penelitian tindakan kelas kolaboratif yaitu peneliti bekerjasama dengan guru kelas dalam melaksanakan penelitian. Penelitian ini direncanakan dan dilaksanakan di SDN 2 Klapasawit. Subjek penelitian ini adalah siswa kelas V SDN 2 Klapasawit tahun ajaran 2017/2018 yang berjumlah 20 siswa.

Teknik pengumpulan data dalam penelitian ini dilakukan menggunakan instrumen berupa lembar observasi terhadap guru dan siswa, pedoman wawancara, tes. Analisis data dalam penelitian ini berupa data kuantitatif dan data kualitatif. Analisis data kualitatif menurut Miles dan Huberman (dalam Sugiyono, 2015: 338-345) meliputi reduksi data, penyajian data, dan penarikan kesimpulan. Validitas data dalam penelitian ini menggunakan triangulasi sumber data dan teknik. Triangulasi sumber data dengan melibatkan guru, siswa, dan dokumen. Triangulasi teknik yaitu observasi, wawancara, dan tes. Indikator kinerja peningkatan pembelajaran matematika dalam penelitian ini yaitu mencapai $85 \%$.

Penelitian ini dilaksanakan dalam tiga siklus. Setiap siklus terdiri dari dua pertemuan. Prosedur penelitian tindakan kelas dalam penelitian ini yaitu perencanaan, pelaksanaan, pengamatan, dan refleksi (Arikunto, 2013: 137). Pada perencanaan penggunaan model Problem Based Learning dengan media kartu domino, peneliti menyusun RPP dan perangkat lainnya, melakukan koordinasi dengan guru kelas dan 
menghubungi observer yang akan bertugas. Pada pelaksanaan guru melaksanakan pembelajaran sesuai perencanaan yang telah dibuat. Pada pengamatan, observer mengamati langkah-langkah penggunaan model Problem Based Learning dengan media kartu domino terhadap guru dan siswa. Pada tahap refleksi dilakukan oleh peneliti, guru kelas, dan observer untuk mendiskusikan kendala yang dihadapi selama pelaksanaan dan mencari solusi agar kendala tersebut dapat diatasi.

\section{HASIL DAN PEMBAHASAN}

Penelitian dilaksanakan dalam tiga siklus. Setiap siklus terdiri dari dua pertemuan. Pelaksanaan pembelajaran dengan menggunakan model Problem Based Learning dengan media kartu domino telah dilaksanakan sesuai dengan skenario pembelajaran yang telah dibuat. Langkah model Problem Based Learning dengan media kartu domino, yaitu (1) orientasi masalah, (2) pengorganisasian belajar, (3) pembimbingan siswa, (4) penyajian hasil kerja, (5) analisis dan evaluasi proses pemecahan masalah.

Pelaksanaan pembelajaran menggunakan model Problem Based Learning dengan media kartu domino yang dilakukan meningkatkan pembelajaran matematika. Peningkatan pembelajaran matematika dapat dilihat dari persentase hasil belajar siswa pada tabel 1 di bawah ini:

\begin{tabular}{ccc}
\multirow{2}{*}{ Tabel 1. Perbandingan Persentase } & $\begin{array}{c}\text { Hasil Belajar Siswa } \\
\text { Hasil Belajar Siswa }\end{array}$ \\
\hline \multirow{2}{*}{$\begin{array}{c}\text { Tindak } \\
\text { an }\end{array}$} & $\begin{array}{c}\text { Nilai } \\
\text { Rata-rata }\end{array}$ & $\begin{array}{c}\text { Persentase } \\
\text { Ketuntasan }\end{array}$ \\
\cline { 2 - 3 } I & 87,5 & $92,5 \%$ \\
\hline II & 90,5 & $87,5 \%$ \\
\hline III & 83,0 & $85,0 \%$ \\
\hline
\end{tabular}

Tabel 1 disimpulkan bahwa nilai hasil belajar siswa mengalami peningkatan. Hal itu terbukti dari nilai rata-rata pada siklus I 87,5 dengan persentase ketuntasan $92,5 \%$. Pada siklus II nilai rata-rata meningkat menjadi 90,5 dengan persentase $87,5 \%$. Pada siklus III nilai rata-rata menjadi 83 dengan persentase ketuntasan $85 \%$. Data hasil belajar siswa menunjukkan bahwa terjadi peningkatan persentase ketuntasan dan nilai rata-rata hasil tes tertulis.

Dalam penelitian ini menemui beberapa kendala yang ditemui pada ketiga siklus yaitu: (1) guru kurang memperhatikan waktu, (2) siswa masih ramai, (3) siswa belum mencatat simpulan, (4) siswa belum percaya diri, (5) masih ada siswa yang pasif. Solusi dari kendala-kendala tersebut, yaitu: (1) guru lebih mengefektifkan waktu, (2) guru memberi arahan agar tenang, (3) guru meminta siswa agar mencatat simpulan, (4) guru memberi motivasi agar siswa percaya diri, (5) guru memberi arahan agar siswa lebih aktif dalam pembelajaran.

\section{SIMPULAN}

Berdasarkan hasil penelitian dapat disimpulkan bahwa penggunaan model Problem Based Learning dengan media kartu domino dapat meningkatkan pembelajaran matematika pada siswa kelas V SDN 2 Klapasawit tahun ajaran 2017/2018. Peningkatan rata-rata nilai dan persentase ketuntasan hasil belajar siswa pada siklus I 87,5 dengan persentase ketuntasan $92,5 \%$. Pa-da siklus II nilai rata-rata meningkat menjadi 90,5 dengan persentase $87,5 \%$. Pada siklus III nilai rata-rata menjadi 83 dengan persentase ketuntasan $85 \%$. 


\section{DAFTAR PUSTAKA}

Amir, T. (2009). Inovasi Pendidikan Melalui Problem Based Learning. Jakarta: Prenadamedia Group.

Arikunto. (2013). Prosedur Penelitian. Jakarta: Rineka Cipta.

Huda, M. (2014). Model-Model Pengajaran dan Pembelajaran. Yogyakarta: Pustaka Pelajar.

Nugraha, D. S. (2016). Penggunaan Media Edukatif Permainan Domino Sebagai Upaya Meningkatkan Hasil Belajar Biologi Siswa Kelas XE SMA Taruna Nusa Harapan Mojokerto Pada Materi Plantae. Yogyakarta: Universitas Sanata Dharma.

Sugiyono. (2015). Metode Penelitian Pendidikan. Bandung Alfabeta.

Wahyudi. (2015). Panduan Pembelajaran Matematika Sekolah Dasar (Untuk Guru dan Calon Guru SD). Surakarta: UNS Press. 